\title{
Immunomodulatory Roles of Polysaccharide Capsules in the Intestine
}

\author{
Samantha A. Hsieh and Paul M. Allen* \\ Department of Pathology and Immunology, Washington University School of Medicine, St. Louis, MO, United States
}

The interplay between the immune system and the microbiota in the human intestine dictates states of health vs. disease. Polysaccharide capsules are critical elements of bacteria that protect bacteria against environmental and host factors, including the host immune system. This review summarizes the mechanisms by which polysaccharide capsules from commensal and pathogenic bacteria in the gut microbiota modulate the innate and adaptive immune systems in the intestine. A deeper understanding of the roles of polysaccharide capsules in microbiota-immune interactions will provide a basis to harness their therapeutic potential to advance human health.

OPEN ACCESS

Edited by:

Laurel L. Lenz,

University of Colorado, United States

Reviewed by:

Christopher Michael Reilly,

Edward via College of Osteopathic

Medicine, United States

Maryam Dadar,

Razi Vaccine and Serum Research

Institute, Iran

*Correspondence:

Paul M. Allen

pallen@wustl.edu

Specialty section:

This article was submitted to Microbial Immunology,

a section of the journal

Frontiers in Immunology

Received: 09 January 2020 Accepted: 26 March 2020 Published: 15 April 2020

Citation:

Hsieh SA and Allen PM (2020) Immunomodulatory Roles of Polysaccharide Capsules in the Intestine. Front. Immunol. 11:690. doi: 10.3389/fimmu.2020.00690
Keywords: polysaccharide capsules, adaptive immunity, innate immunity, regulatory $\mathrm{T}$ cells, antigen processing, intestinal microbiota

\section{INTRODUCTION}

The dynamic interactions between the gut microbiota and immune system determine whether immune tolerance or inflammation and disease develop in the human intestine. One component of bacteria that has been found to play an important role in regulating immune responses in the gut are polysaccharide capsules. Polysaccharide capsules are long polysaccharide chains that form the outermost layer of bacteria and can be several $100 \mu \mathrm{m}$ thick (1). Capsules are thought to be critical for bacterial fitness and provide protection against many environmental and host factors, especially since they are often the first bacterial structural encountered by the host immune system (2). The study of bacterial capsules had a key role in the early days of molecular biology with the seminal studies of Avery, MacLeod, and McCarty showing that DNA was the genetic material (3). They studied two strains of Streptococcus pneumoniae, smooth (S) and rough (R), which were virulent and avirulent, respectively. The $S$ strain produced a capsule, whereas the $\mathrm{R}$ strain did not. They were able to transform the $\mathrm{R}$ strain into an avirulent $\mathrm{S}$ strain using DNA from the $\mathrm{S}$ strain, thereby proving that DNA was the genetic material (3).

One striking feature of the capsules in general is their chemical and structural diversity within a given bacterial species. They can be composed of different monosaccharides, which can also vary in their stereoisomers (D or L), number of carbon molecules forming the sugar ring structure (furanose or pyranose), and configuration of the anomeric center of each sugar (C $\alpha$ or $\mathrm{C} \beta$ ) (4). These polysaccharides can be further diversified by branching and glycosidic linkage patterns $(\alpha$ or $\beta$ ), covalent coupling to other biological molecules such as proteins and lipids, and forming secondary structures (5). This astronomical diversity likely equips polysaccharide capsules with many different functions that enhance bacterial fitness.

Polysaccharide capsules have been shown to enhance bacterial survival in the gut by multiple mechanisms. Capsule composition varies with diet and different capsules may provide optimal access to various nutrients and more efficient use of the bacterial cell's resources (5). Another role 
of polysaccharide capsules in the gut microbiota is exclusion of pathogens as capsule expression has been shown to alter disease symptoms as well as bacterial attachment to host cells and thus bacterial abundance (5). Capsules can be degraded by other microbes, which can be either beneficial or detrimental to the bacteria. In mutualistic relationships, they can be used as a nutrient source for neighboring bacteria. However, capsules can also be degraded by competing bacteria, reducing bacterial fitness. Capsules have also been shown to provide protection against bacteriophages (5). In addition, polysaccharide capsules can alter immune responses to bacteria. Interestingly, even minor differences between capsules can completely alter the immune response as each is recognized as immunologically distinct (4).

Some bacteria, especially the Bacteroides species, express polysaccharide capsules that are phase variant and are able to switch between different capsules (6). This phase variance arises because each polysaccharide can regulate its expression using a reversible on-off phenotype, which is controlled by inversions of the DNA promoter regions that lie upstream of their polysaccharide biosynthesis loci (7). These inversions place the promoters in either the correct or incorrect orientation for transcription of the downstream polysaccharide biosynthesis genes. Phase variation is thought to equip bacteria to adapt and survive in different niches in the gut and may be especially advantageous in the face of immune pressure by enabling bacteria to alter their surface antigenicity (5).

The two main types of polysaccharide capsules are exopolysaccharides (EPSs) and capsular polysaccharides (CPSs). EPSs contain glycans that are loosely associated with microbial cell surfaces, while CPSs are composed of glycans that are firmly attached to the cell surface (5). However, determining whether or not glycans are attached to the cell surface is difficult, so these terms are often used interchangeably. In this review, we will use the term microbially produced glycans (MPGs) to encompass both CPSs and EPSs (5). MPGs have been found in a variety of Gram-negative and Gram-positive bacteria including Escherichia coli, Neisseria meningitides, Haemophilus influenza, Staphylococcus aureus, and Streptococcus pneumoniae and are critical for serological classification and vaccine development (2). Although the roles of MPGs in the gut microbiota are less understood, there have been many recent advances in understanding the interplay between bacterial MPGs and the host immune system in the intestine. Here we review the current literature on the immunomodulatory roles of MPGs in the intestine on both innate and adaptive immune responses. A summary of the effects of different MPSs, their capsule composition, immune cell target, and mechanisms of action are detailed in Table 1.

\section{MPGS MODULATE INNATE IMMUNE RESPONSES IN THE INTESTINE}

The innate immune system is the first line of defense against many pathogens, and MPGs have been shown to be critical for regulating innate immune responses in the gut. One mechanism the innate system uses to combat bacterial infection is the production of antimicrobial peptides such as defensins and cathelicidins by the intestinal epithelium. MPGS can block the bactericidal activity of antimicrobial factors, enabling bacteria to evade these innate immune responses. For example, wildtype (WT) enteropathogenic Escherichia coli (EPEC) was more resistant to human $\alpha$-defensin 5 (HD-5) than an unencapsulated EPEC mutant (35). An unencapsulated EPEC strain could be protected from HD-5 killing by the addition of exogenous EPEC polysaccharide, suggesting that the EPEC capsule likely binds HD-5 and traps it before it reaches the bacterial membrane (35). Similarly, EPS from the probiotic Lactobacillus rhamnosus GG (LGG) protected LGG from the LL-37/human cationic protein 18 from the cathelicidin family (42). Viability of an EPS ${ }^{-}$LGG strain was reduced in the presence of LL-37, while an EPS ${ }^{+}$LGG strain had no change in viability. In addition, growing LGG in the presence of subinhibitory concentrations of LL-37 induced EPS expression, further demonstrating that EPSs protect microbes from antimicrobial peptides (42).

Another method the innate immune system uses to recognize and destroy bacteria is complement. MPGs can block the deposition of complement on bacterial surfaces, which prevents bacteria from being targeted for destruction by the immune system. EPS from LGG also protected against complementmediated lysis as an $\mathrm{EPS}^{-}$LGG strain, but not an $\mathrm{EPS}^{+}$ LGG strain, had a reduction in viability after incubation with normal human serum (42). Although WT Salmonella enterica serovar Typhimurium was resistant to killing by normal human serum, an EPS ${ }^{-}$strain had increased serum sensitivity as well as faster C3 surface deposition (46). Similarly, an unencapsulated strain of Shigella sonnei was more vulnerable to complement than WT and also had a reduced ability to disseminate peripherally (50). Vibrio cholera's CPS also protects against complement-mediated bacteriolysis and strains isolated from patients that contained less capsular material were more susceptible to the bactericidal activity of serum $(53,54)$. The CPS of Campylobacter jejuni blocks antibody binding and activation of complement and non-stoichiometric O-methyl phosphoramidate (MeOPN) modifications at the 4 position of galactose has been shown to be the most critical to complement resistance (33). An acapsular strain of the Gram-negative symbiont Bacteroides thetaiotaomicron, which lacks expression of all B. thetaiotaomicron CPSs, also had a decrease in survival after treatment with normal human serum compared to WT, further suggesting that CPSs can enable bacteria to circumvent complement (25). Interestingly, B. thetaiotaomicron strains that singly expressed different CPSs had varying susceptibilities to normal human serum as CPS2, CPS4, CPS5, CPS6, and WT were more resistant to complement than CPS1, CPS3, CPS7, and CPS8 (25). These findings demonstrate that MPGs can protect bacteria by inhibiting complement deposition on the surface of bacteria, which prevents complement-mediated lysis as well as uptake by phagocytic cells.

MPGs can also directly block bacterial uptake by innate immune cells, which prevents phagocytic cells from killing bacteria and antigen presenting cells from presenting antigenic peptides on the surfaces that may activate the adaptive immune system. For example, B. thetaiotaomicron with anti-stimulatory 
TABLE 1 | Summary of the effects of bacterial polysaccharide capsules in the intestine on the immune system.

\begin{tabular}{|c|c|c|c|c|c|c|c|c|}
\hline Bacteria & $\begin{array}{l}\text { Gram } \\
\text { stain }\end{array}$ & $\begin{array}{l}\text { Commensal/ } \\
\text { Pathogen }\end{array}$ & MPG & Capsule composition & $\begin{array}{l}\text { Immune cell } \\
\text { target }\end{array}$ & Mechanism & $\begin{array}{l}\text { Targeted immune } \\
\text { pathways }\end{array}$ & References \\
\hline Bacillus subtilis & Gram + & Commensal & EPS & $\begin{array}{l}\text { Mannose (88\%), glucose (11.9\%), } \\
N \text {-acetylglucosamine (0.1\%); Primary linkages: } \\
\text { 2,6-mannose (31.8\%), terminal mannose } \\
(29.9 \%) \text {, 3-mannose (15\%), 2-mannose (4.7\%), } \\
\text { 6-mannose (4.7\%), 6-glucose (3.7\%), and } \\
\text { terminal glucose (3.5\%) }\end{array}$ & Macrophages & $\begin{array}{l}\text { Signals through TLR4/MyD88 pathway to } \\
\text { induce M2 macrophages, which inhibit CD4+ T } \\
\text { cells via TGF- } \beta \text { and CD8 }+ \text { T cells via TGF- } \beta \\
\text { and PD-L1; protects against C. } \\
\text { rodentium-induced colitis }\end{array}$ & $\begin{array}{l}\text { Macrophage skewing; } \\
\text { T cell activation }\end{array}$ & $(8,9)$ \\
\hline $\begin{array}{l}\text { Bacteroides } \\
\text { cellulosilyticus }\end{array}$ & Gram - & Commensal & CPS & $\begin{array}{l}\text { Acetamido-amino-2,4,6-trideoxygalactose } \\
\text { (AATGal) amino sugar; zwitterionic }\end{array}$ & Monocytes & $\begin{array}{l}\text { Induces IL-10 and } \\
\text { CD25+FoxP3+CD127-CTLA-4+ Tregs; } \\
\text { attenuates TNBS-induced colitis }\end{array}$ & $\begin{array}{l}\text { Cytokine production; } T \\
\text { cell activation }\end{array}$ & (10) \\
\hline Bacteroides fragilis & Gram - & Commensal & $\begin{array}{l}\text { CPS: } \\
\text { PSA }\end{array}$ & $\begin{array}{l}\text { Tetrasaccharide repeating unit containing } \\
\text { 4,6-pyruvate attached to a d-galactopyranose, } \\
\text { 2,4-dideoxy-4-amino-d-FucNAc, } \\
\text { d-N-acetylgalactosamine, and } \\
\text { d-galactofuranose with one positively charged } \\
\text { free amine and one negatively charged } \\
\text { carboxylate; zwitterionic }\end{array}$ & Dendritic cells & $\begin{array}{l}\text { Enhances antigen presentation by upregulating } \\
\text { MHC II, CD80, and CD86; phagocytosed by } \\
\text { APCs and displayed on MHC II to activate } \\
\text { CD4+ T cells in a TLR2-dependent manner; } \\
\text { corrects CD4+ T cell deficiencies and } T_{H} 1 / T_{H} 2 \\
\text { imbalance in germ-free mice by upregulating } \\
\text { the production of IFN- } \gamma+T_{H} 1 \mathrm{~T} \text { cells through } \\
\text { CD11C+ DCs and the IL-12/STAT4 pathway; } \\
\text { represses } T_{H} 17 \text { responses; induces IL-10 } \\
\text { producing FoxP3+ Tregs in a TLR2-dependent } \\
\text { manner; protects against TNBS-induced colitis } \\
\text { and Helicobacter hepaticus-induced colitis; } \\
\text { OMVs }\end{array}$ & $\begin{array}{l}\text { Antigen presentation; } T \\
\text { cell activation }\end{array}$ & $(11-23)$ \\
\hline $\begin{array}{l}\text { Bacteroides } \\
\text { thetaiotaomicron }\end{array}$ & Gram - & Commensal & $\begin{array}{l}\text { CPS: } \\
\text { CPS 1-8 }\end{array}$ & 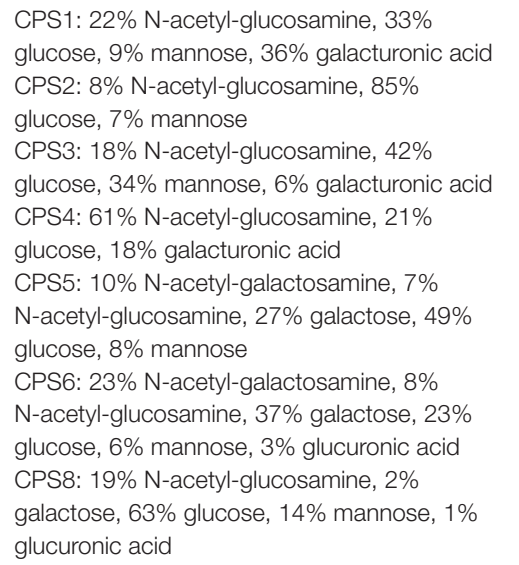 & $\begin{array}{l}\text { Dendritic } \\
\text { cells, } \\
\text { macrophages }\end{array}$ & $\begin{array}{l}\text { CPS2, CPS4, CPS5, CPS6, and WT are more } \\
\text { resistant to complement; CPS1-6 inhibit APC } \\
\text { phagocytosis and antigen presentation likely } \\
\text { due to increased capsule thickness and } \\
\text { decrease IL-6 and TNF- } \alpha \text { production in a } \\
\text { MyD88-dependent manner; CPS5 promotes } \\
\text { evasion of IgA responses; CPS1 represses } \\
\text { polyclonal and antigen-specific T cell activation } \\
\text { and differentiation to IFN- } \gamma+\text { IL-17A+ T cells; } \\
\text { OMVs }\end{array}$ & $\begin{array}{l}\text { Complement evasion; } \\
\text { phagocytosis; antigen } \\
\text { presentation; cytokine } \\
\text { production; evasion of } \\
\text { antibody responses; T } \\
\text { cell activation }\end{array}$ & $(24,25)$ \\
\hline $\begin{array}{l}\text { Bifidobacterium } \\
\text { bifidum }\end{array}$ & Gram + & Commensal & CPS & $\begin{array}{l}\text { Mixture of four neutrally charged cell surface } \\
\beta \text {-glucan/galactan }(C S G G) \text { polysaccharides: } \\
\beta-(1 \rightarrow \text { 6)-glucan, } \beta \text {-( }(\rightarrow 4) \text {-galactan, } \beta \text { - }(1 \\
\rightarrow 6) \text {-galactan, } \beta \text {-galactofuranan and starch }\end{array}$ & Dendritic cells & $\begin{array}{l}\text { induces IL-10 and FoxP3+ Tregs through } \\
\text { TLR2-mediated mechanism on DCs; } \\
\text { attenuates colitis in T cell transfer model of } \\
\text { colitis }\end{array}$ & $\begin{array}{l}\text { Cytokine production; } T \\
\text { cell activation }\end{array}$ & $(26,27)$ \\
\hline
\end{tabular}


TABLE 1 | Continued

\begin{tabular}{|c|c|c|c|c|c|c|c|c|}
\hline Bacteria & $\begin{array}{l}\text { Gram } \\
\text { stain }\end{array}$ & $\begin{array}{l}\text { Commensal/ } \\
\text { Pathogen }\end{array}$ & MPG & Capsule composition & $\begin{array}{l}\text { Immune cell } \\
\text { target }\end{array}$ & Mechanism & $\begin{array}{l}\text { Targeted immune } \\
\text { pathways }\end{array}$ & References \\
\hline $\begin{array}{l}\text { Bifidobacterium } \\
\text { breve }\end{array}$ & Gram + & Commensal & EPS & $\begin{array}{l}\text { Glucose, galactose and/or the } \mathrm{N} \text {-acetylated } \\
\text { versions of these two sugars }\end{array}$ & B cells & $\begin{array}{l}\text { Decreases numbers of B cells and } \\
\text { antigen-specific total Ig, IgG3, IgG1, IgG2a, } \\
\text { and fecal lgA titers; elicits weaker antibody } \\
\text { responses by masking surface antigens }\end{array}$ & $\begin{array}{l}\text { B cell activation; masks } \\
\text { surface antigens }\end{array}$ & $(28,29)$ \\
\hline $\begin{array}{l}\text { Bifidobacterium } \\
\text { longum }\end{array}$ & Gram + & Commensal & EPS & $\begin{array}{l}\text { Branched hexasaccharide repeating unit with } \\
\text { two galactoses, two glucoses, galacturonic } \\
\text { acid, and the unusual sugar 6-deoxytalose }\end{array}$ & $\begin{array}{l}\text { Neutrophils, } \\
\text { macrophages, } \\
\text { dendritic } \\
\text { cells, NK cells }\end{array}$ & $\begin{array}{l}\text { Decrease IFN- } \gamma, \text { IL-12, TNF- } \alpha \text {, IL- } 17 \text {, IL-6 } \\
\text { production; prevents phagocytosis; represses } \\
\mathrm{T}_{H} 17 \text { recruitment; protects against T cell } \\
\text { transfer model of colitis }\end{array}$ & $\begin{array}{l}\text { Cytokine production; } \\
\text { phagocytosis; } T \text { cell } \\
\text { activation }\end{array}$ & (30-32) \\
\hline $\begin{array}{l}\text { Campylobacter } \\
\text { jejuni }\end{array}$ & Gram - & Pathogen & CPS & $\begin{array}{l}\text { Heptoses in unusual configurations (e.g., ido, } \\
\text { gulo, and altro) and non-stoichiometric } \\
\text { modifications on the sugars, including } \\
\text { ethanolamine, aminoglycerol, and O-methyl } \\
\text { phosphoramidate (MeOPN) }\end{array}$ & $\begin{array}{l}\text { Dendritic } \\
\text { cells, } \\
\text { macrophages }\end{array}$ & $\begin{array}{l}\text { Blocks antibody binding and activation of } \\
\text { complement; decreases activation of TLR } 4 \text { and } \\
\text { production of IL-1 } 1 \beta \text {, IFN- } \gamma \text {, and IL-6 }\end{array}$ & Complement evasion & $(33,34)$ \\
\hline $\begin{array}{l}\text { Enteropathogenic } \\
\text { Escherichia coli }\end{array}$ & Gram - & Pathogen & $\begin{array}{l}\text { CPS: Gp } \\
4 \\
\text { capsule }\end{array}$ & $\begin{array}{l}\text { Linear tetrasaccharide made of L-fucose, } \\
\text { D-galactose and two } \mathrm{N} \text {-acetyl-galactosamines }\end{array}$ & $\begin{array}{l}\text { Human } \\
\alpha \text {-defensin } 5\end{array}$ & $\begin{array}{l}\text { Uses its anionic charges to prevent cationic } \\
\text { human } \alpha \text {-defensin } 5 \text { from reaching the bacterial } \\
\text { membrane }\end{array}$ & $\begin{array}{l}\text { Innate immune evasion } \\
\text { of antimicrobial } \\
\text { peptides }\end{array}$ & (35) \\
\hline $\begin{array}{l}\text { Faecalibacterium } \\
\text { prausnitzii }\end{array}$ & Gram + & Commensal & EPS & Unknown & Dendritic cells & $\begin{array}{l}\text { Decreases IL-12p70 and IFN- } \gamma \text { and increases } \\
\text { IL-10 secretion through TLR2 signaling by } \\
\text { Lactobacillus plantarum; induces Foxp3+ } \\
\text { CD4+ T cells }\end{array}$ & $\begin{array}{l}\text { Cytokine production; } \\
\text { attenuates DSS-colitis }\end{array}$ & (36) \\
\hline $\begin{array}{l}\text { Helicobacter } \\
\text { hepaticus }\end{array}$ & Gram - & Pathobiont & CPS & $\alpha$-mannose and $\alpha$-glucose sugars & Macrophages & $\begin{array}{l}\text { Signals through TLR2/MyD88 pathway to } \\
\text { activate MSK/CREB pathway and induce IL-10 }\end{array}$ & $\begin{array}{l}\text { Innate immune } \\
\text { tolerance }\end{array}$ & (37) \\
\hline $\begin{array}{l}\text { Lactobacillus } \\
\text { fermentum }\end{array}$ & Gram + & Commensal & EPS & 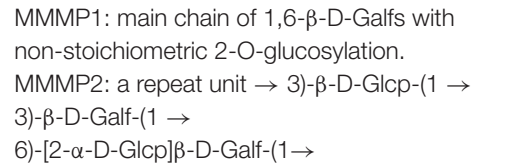 & Unknown & Induces IgA production & $\begin{array}{l}\text { Enhances IgA } \\
\text { production }\end{array}$ & (38) \\
\hline $\begin{array}{l}\text { Lactobacillus } \\
\text { johnsonii }\end{array}$ & Gram + & Commensal & EPS & $\begin{array}{l}\text { EPS-1: branched dextran with every backbone } \\
\text { residue substituted with a } 2 \text {-linked glucose unit } \\
\text { and polysaccharides partially occupied by } \\
\text { 1-phosphoglycerol and O-acetyl groups; } \\
\text { EPS-2: repeating unit } \\
\text { with-6)- } \alpha \text {-Glcp-(1-3)- } \beta \text {-Glcp-(1-5)- } \beta \text {-Galf-(1- } \\
\text { 6)- } \alpha \text {-Glcp-(1-4)- } \beta \text {-Galp-(1-4)- } \beta \text {-Glcp-(1-and } \\
\text { polysaccharides partially occupied by single } \\
\text { O-acetyl group }\end{array}$ & Unknown & Masks cell surface epitopes from antibodies & Masks surface antigens & (39) \\
\hline $\begin{array}{l}\text { Lactobacillus } \\
\text { kefiranofacien }\end{array}$ & Gram + & Commensal & EPS & Equal proportions of glucose and galactose & & Induces IgA production & $\begin{array}{l}\text { Enhances IgA } \\
\text { production }\end{array}$ & (40) \\
\hline $\begin{array}{l}\text { Lactobacillus } \\
\text { rhamnosus GG }\end{array}$ & Gram + & Commensal & EPS & $\begin{array}{l}70 \% \text { galactose, } 19 \% \text { rhamnose, and } 10 \% \\
\text { glucose }\end{array}$ & $\begin{array}{l}\text { LL-37/human } \\
\text { cationic } \\
\text { protein } 18 \\
\text { complement }\end{array}$ & $\begin{array}{l}\text { Resists cationic LL-37/human cationic protein } \\
18 \text { by forming protective shield with long and } \\
\text { neutral EPS; protects against complement } \\
\text { activation and lysis via lack of mannose }\end{array}$ & $\begin{array}{l}\text { Innate immune evasion } \\
\text { of antimicrobial } \\
\text { peptides; complement } \\
\text { evasion }\end{array}$ & $(41,42)$ \\
\hline
\end{tabular}


TABLE 1 | Continued

\begin{tabular}{|c|c|c|c|c|c|c|c|c|}
\hline Bacteria & $\begin{array}{l}\text { Gram } \\
\text { stain }\end{array}$ & $\begin{array}{l}\text { Commensal/ } \\
\text { Pathogen }\end{array}$ & MPG & Capsule composition & $\begin{array}{l}\text { Immune cell } \\
\text { target }\end{array}$ & Mechanism & $\begin{array}{l}\text { Targeted immune } \\
\text { pathways }\end{array}$ & References \\
\hline $\begin{array}{l}\text { Leuconostoc } \\
\text { mesenteroides }\end{array}$ & Gram + & Commensal & EPS & Glucose and fructose & Unknown & $\begin{array}{l}\text { Induces IgA production, retinoic acid synthase, } \\
\text { and TGF- } \beta \text {; increases number of CD4+ and } \\
\text { CD8+ T cells }\end{array}$ & $\begin{array}{l}\text { Enhances IgA } \\
\text { production; cytokine } \\
\text { production; T cell } \\
\text { activation }\end{array}$ & (43) \\
\hline $\begin{array}{l}\text { Pediococcus } \\
\text { parvulus }\end{array}$ & Gram + & Commensal & EPS & 2-substituted $(1,3)-\beta$-d-glucan & Macrophages & Decreases TNF- $\alpha$ and IL-8 production & Cytokine production & (44) \\
\hline $\begin{array}{l}\text { Salmonella } \\
\text { enterica serovar } \\
\text { Typhimurium }\end{array}$ & Gram - & Pathogen & $\begin{array}{l}\text { CPS: Gp } \\
4 \mathrm{cp} \\
\text { (O-ag } \\
\text { CPS) }\end{array}$ & $\begin{array}{l}\text { Repeating units of glucose, mannose, and } \\
\text { galactose }\end{array}$ & $\begin{array}{l}\text { Complement; } \\
\text { macrophages }\end{array}$ & $\begin{array}{l}\text { Decreases C3 surface deposition; decreases } \\
\text { production of IL-6 and TNF- } \alpha \text { in a } \\
\text { TLR-dependent manner }\end{array}$ & $\begin{array}{l}\text { Complement evasion; } \\
\text { cytokine production }\end{array}$ & $(45-47)$ \\
\hline Salmonella Typhi & Gram - & Pathogen & CPS: Vi & $\begin{array}{l}\text { Homopolymer of }(1,4)-2 \text {-acetamido-3-O- } \\
\text { acetyl-2-deoxy- } \alpha \text {-D-galacturonic } \\
\text { acid }\end{array}$ & T cells & $\begin{array}{l}\text { Represses T cell responses by binding to T } \\
\text { cells through the prohibitin complex and } \\
\text { inhibiting IL-2 secretion; prevents } \mathrm{C} 3 \\
\text { deposition, phagocytosis, and complement } \\
\text { receptor 3-mediated clearance }\end{array}$ & $\begin{array}{l}\text { Represses T cells; } \\
\text { complement evasion }\end{array}$ & $(48,49)$ \\
\hline Shigella sonnei & Gram - & Pathogen & $\begin{array}{l}\text { CPS: Gp } \\
4 \mathrm{cp} \\
\text { (O-ag } \\
\text { CPS) }\end{array}$ & $\begin{array}{l}\text { High molecular weight polysaccharide } \\
\text { containing FucNAc } 4 N \text { and L-AltNAcA residues } \\
\text { in 1:1 ratio }\end{array}$ & Complement & Resists direct complement-mediated killing & Complement evasion & (50) \\
\hline $\begin{array}{l}\text { Streptococcus } \\
\text { thermophiles }\end{array}$ & Gram + & Commensal & EPS & $\begin{array}{l}12.9 \% \text { rhamnose, } 26 \% \text { glucose, } 60.9 \% \\
\text { galactose, } 0.25 \% \text { mannose }\end{array}$ & Unknown & Decreases IFN- $\gamma$, IL-6, and TNF- $\alpha$ production & Cytokine production & (51) \\
\hline Vibrio cholerae & Gram - & Pathogen & $\begin{array}{l}\text { CPS }(\mathrm{O}- \\
\text { antigen } \\
\text { CPS) }\end{array}$ & $\begin{array}{l}\text { Polymerized O-antigen subunits composed of } \\
\mathrm{N} \text {-acetylglucosamine, } \mathrm{N} \text {-acetyl-quinovosamine, } \\
\text { galacturonic acid, galactose andcolitose }\end{array}$ & Complement & $\begin{array}{l}\text { Resists complement-mediated bacteriolysis } \\
\text { likely by promoting binding of negative } \\
\text { regulatory proteins and inhibiting efficient } \\
\text { complement fixation at the bacterial surface }\end{array}$ & Complement evasion & $(52,53)$ \\
\hline
\end{tabular}

Microbially produced glycan (MPG), exopolysaccharide (EPS), capsular polysaccharide (CPS), antigen presenting cell (APC), medium molecular mass exopolysaccharide (MMMP1), and 2,4,5-trinitrobenzene sulfonic acid (TNBS). 
CPSs such as CPS1 are poorly uptaken by bone-marrow macrophages (BMDM) and splenic CD11c+ dendritic cells (DCs) (24). In contrast, B. thetaiotaomicron expressing prostimulatory CPSs such as CPS8 or Acap are readily phagocytosed. These differences in phagocytosis may be partly explained by the thicknesses of the B. thetaiotaomicron CPSs as anti-stimulatory CPSs tended to be thicker than pro-stimulatory CPSs. In support of these findings, $B$. thetaiotaomicron expressing anti-stimulatory CPSs were cleared less effectively from the peritoneal cavity than $B$. thetaiotaomicron expressing pro-stimulatory CPSs in vivo, likely because anti-stimulatory CPSs inhibited uptake by peritoneal innate immune cells (24). In addition, innate immune phagocytes cultured with $B$. thetaiotaomicron expressing antistimulatory CPSs were poor antigen presenters to the adaptive immune system. Bifidobacterium longum's EPS also inhibited macrophage phagocytosis (32). In contrast, other MPGs can promote the maturation of innate immune cells so that they serve as better antigen presenting cells (APCs) to the adaptive immune system. For example, the polysaccharide A capsule (PSA) expressed on Bacteroides fragilis upregulates MHC II expression on CD11c+ dendritic cells as well as the costimulatory molecules CD80 and CD86, which enhances antigen presentation (18).

Innate immune responses to bacteria can also be thwarted by MPGs that promote immune tolerance by inducing innate immune cells to release anti-inflammatory cytokines in the intestine. A large soluble polysaccharide released by the Gramnegative Helicobacter hepaticus induced an anti-inflammatory M2 gene signature as well as IL-10 production in intestinal macrophages through TLR2, mitogen and stress-activated protein kinase (MSK), and cyclic AMP response-element binding protein (CREB) (37). Similarly, the EPS from the Grampositive probiotic Bacillus subtilis elicited anti-inflammatory M2 macrophages through TLR4, which was required for EPSmediated protection from Citrobacter rodentium-induced colitis $(8,9)$ and limited inflammation during Staphylococcus aureus infection (55).

Other MPGs protect bacteria from innate immune responses by reducing the production of pro-inflammatory cytokines by innate immune cells. Anti-stimulatory CPSs expressed on $B$. thetaiotaomicron decreased the levels of the pro-inflammatory cytokines IL- 6 and TNF- $\alpha$ produced by macrophages and dendritic cells (DCs) in the presence of $B$. thetaiotaomicron (24). Neutrophils, macrophages, and NK cells each produced less IFN- $\gamma$, IL-12, and TNF- $\alpha$ in mice treated with EPS ${ }^{+}$vs. EPS ${ }^{-}$ Bifidobacterium breve (B. breve) (28). EPS from Bifidobacterium longum also induced lower levels of IL-12p70, IFN- $\gamma$, and IL17 in human peripheral blood mononuclear cells and IL-17, IL-6, and TNF- $\alpha$ in human monocyte-derived dendritic cells compared to an $\mathrm{EPS}^{-}$B. longum strain (31). In support of these findings, adding isolated EPS to PBMC cultures with EPS $^{-}$B. longum reduced the secretion of IL-12p70 and IFN$\gamma$ (31). Neutrally charged EPS from the putative probiotic Streptococcus thermophiles also decreased the production of the pro-inflammatory cytokines IFN- $\gamma$, IL- 6 , and TNF- $\alpha$ in DSS-induced colitis (51). The production of TNF- $\alpha$ and IL8 production by human monocyte-derived macrophages was reduced in the presence of an $\mathrm{EPS}^{+}$Pediococcus parvulus strain compared to an $\mathrm{EPS}^{-}$strain (44). Campylobacter jejuni's CPS decreases activation of TLR4 and production of proinflammatory IL-1 $\beta$, IFN- $\gamma$, and IL-6 (33). Expression of Salmonella's Vi capsular polysaccharide led to a decline in IL-6 and TNF- $\alpha$ secretion by BMDM in a TLR-dependent manner (47). In addition, an extracellular polymeric matrix from Faecalibacterium prausnitzii reduced the secretion of proinflammatory IL-12p70 in a TLR2-dependent manner in human monocyte-derived DCs cultured with Lactobacillus plantarum compared to L. plantarum alone (36). These results demonstrate that the gut microbiota also uses MPGs to inhibit innate immune responses by decreasing the production of pro-inflammatory cytokines and increasing the production of anti-inflammatory cytokines by innate immune cells. This induction of innate immune tolerance by MPGs may represent one way innate immune cells are able to distinguish between pathogens and commensal bacteria, although this mechanism can also be coopted by pathogens to evade the innate immune system.

\section{MPGS MODULATE ADAPTIVE IMMUNE RESPONSES IN THE INTESTINE}

The host immune system also consists of adaptive immunity, especially $\mathrm{B}$ and $\mathrm{T}$ cells, which protect the intestine from bacterial pathogens in an antigen-specific manner and induce immunological memory that leads to enhanced immune responses to consequent encounters with pathogens. Bacteria also encounter the adaptive immune system in the intestine, and the ability of MPGs to evade adaptive immune responses is crucial to their fitness and survival in the gut. One mechanism MPGs use to modulate the adaptive immune system is regulating the interactions between B cells, antibodies, and bacteria. Many MPGs inhibit B cell and antibody responses to bacteria. For example, $\mathrm{EPS}^{+}$B. breve-treated mice had decreased numbers of $\mathrm{B}$ cells as well as lower antigen-specific total Ig, IgG3, IgG1, IgG2a, and fecal IgA titers (28). EPS ${ }^{+} B$. breve persisted longer than EPS $^{-} B$. breve in WT mice, but this difference was abolished in $B$ cell-deficient mice, suggesting that EPS on B. breve modulates $B$ cells and plays a role in evading adaptive immune responses. In addition, $\mathrm{EPS}^{+} B$. breve weakly agglutinated with anti-EPS serum, while $\mathrm{EPS}^{-} B$. breve strongly agglutinated with serum from EPS $^{-}$-treated mice but not anti-EPS serum, demonstrating that MPGs can mask surface antigens from detection and thereby elicit weaker antibody responses (28). EPS from the potential probiotic Lactobacillus johnsonii also protected cell surface epitopes from exposure to antibodies as an EPS ${ }^{-}$strain of the potential probiotic Lactobacillus johnsonii bound to more polyclonal antibody raised against WT $L$. johnsonii than an EPS $^{+}$strain. A mutant that overexpressed L. johnsonii EPS had similar levels of bound antibody compared to wild type, indicating that the L. johnsonii EPS itself is poorly recognized by the immune system (39). In germ-free mice that were colonized with all 8 single CPS-expressing $B$. thetaiotaomicron strains, higher levels of IgA production correlated with increased abundance of the CPS5-expressing strain, suggesting that some 
CPSs such as CPS5 may promote evasion of IgA responses (25). In contrast, other MPGs promote the production of antibodies as EPSs from the probiotic lactic acid bacteria Lactobacillus kefiranofaciens, Leuconostoc mesenteroides, and Lactobacillus fermentum induced IgA production in the intestine, which may enhance the protective nature of intestinal barrier $(38,40,43)$. Thus, depending on the MPG, MPGs can either inhibit or bolster $\mathrm{B}$ cell and antibody responses in the intestine.

Many MPGs can also modulate $\mathrm{T}$ cell responses in the intestine, including by functioning as $\mathrm{T}$ cell antigens and by regulating both polyclonal and antigen-specific $\mathrm{T}$ cells. Most polysaccharides are classically considered to be $\mathrm{T}$ cellindependent antigens that do not induce the activation of helper $\mathrm{T}$ cells that stimulate Ig class switching in B cells or immunologic memory (56). Instead, polysaccharides must be coupled to protein carriers in order to enlist $\mathrm{T}$ cell help and induce IgG antibodies and memory B cells such as in vaccines (6). Although carbohydrates are not usually $\mathrm{T}$ cell antigens, zwitterionic polysaccharides (ZPSs), which contain both a positive and negative charge, are unique MPGs that have been shown to regulate $\mathrm{T}$ cells by directly acting as a $\mathrm{T}$ cell antigen. The best studied zwitterionic MPG is the $B$. fragilis PSA. Although PSA is a carbohydrate, PSA can be presented by APCs to activate T cells $(11,12)$. PSA is taken-up into APC endosomes, processed by inducing nitric oxide production through TLR2, and is displayed on major histocompatibility complex (MHC) II to activate CD4+ T cells in mice $(14,16,17,23)$. In human dendritic cells (DCs), the C-type lectin dendritic cell-specific intercellular adhesion molecule-3-grabbing non-integrin (DCSIGN) is the main receptor for PSA (57). PSA's ability to directly stimulate TLR2 has recently come under debate as PSA is not a typical TLR2-stimulating molecular structure and one study suggests that the lipoproteins in $B$. fragilis glycoconjugate fractions are responsible for stimulating TLR2, not PSA (58). PSA is currently the only CPS that has been shown to function as an antigen and is directly presented to T cells.

MPGs have also been shown to be critical for maturation of the host immune system, especially the development of $\mathrm{T}$ cells. Although germ-free mice that lack the bacterial microflora are known to exhibit immunological defects, B. fragilis PSA was sufficient to correct these $\mathrm{T}$ cell deficiencies (18). Monocolonizing germ-free mice with WT $B$. fragilis or purified PSA, but not PSA-deficient $B$. fragilis, corrected the CD4+ T cell deficiencies in germ-free mice. Although PSA had no effect on the proportions of CD8+ T cells or CD19+ B cells, PSA also corrected the $\mathrm{T}_{\mathrm{H}} 1 / \mathrm{T}_{\mathrm{H}} 2$ imbalance in germ-free mice by upregulating the production of IFN $-\gamma+\mathrm{T}_{\mathrm{H}} 1 \mathrm{~T}$ cells through CD11c+ DCs and the IL-12/STAT4 pathway (18).

MPGs can also modulate the activation of polyclonal $\mathrm{T}$ cell responses, especially by directing $\mathrm{T}$ cell differentiation. Most $\mathrm{T}$ cell effects of MPGs that have been studied induce a state of immune tolerance by suppressing $\mathrm{T}$ cell responses. In the Powrie model of colitis, $\mathrm{EPS}^{+} B$. longum induced fewer IL$17 \mathrm{~A}+$ lymphocytes and protected against colitis compared to EPS $^{-}$B. longum (31). Salmonella Typhi capsular polysaccharide $\mathrm{Vi}$ repressed $\mathrm{T}$ cell responses by binding to $\mathrm{T}$ cells through the prohibitin complex and inhibiting IL-2 secretion (48). B. thetaiotaomicron expressing anti-stimulatory CPSs were also found to activate polyclonal $\mathrm{T}$ cells in germ-free mice more weakly than $B$. thetaiotaomicron expressing pro-stimulatory CPSs (24). In addition, $B$. fragilis PSA repressed $\mathrm{T}_{\mathrm{H}} 17$ cell responses, which is required for $B$. fragilis colonization, as $B$. fragilis lacking PSA was unable to restrain $\mathrm{T}_{\mathrm{H}} 17$ cell responses through TLR2 in contrast to WT B. fragilis (21). Many MPGs also direct polyclonal $\mathrm{T}$ cells to differentiate into regulatory $\mathrm{T}$ cells $\left(\mathrm{T}_{\text {regs }}\right)$ that often suppress effector $\mathrm{T}$ cells as well as intestinal inflammation. $B$. fragilis PSA induces the differentiation of IL-10 producing FoxP3 $+\mathrm{T}_{\text {regs }}$ in mice in a TLR2-dependent manner, which can protect against TNBS-induced colitis and experimental colitis induced by Helicobacter hepaticus (15, 19, $20,22)$. PSA can also generate human IL-10 producing $\mathrm{T}_{\text {regs }}$ in vitro $(22,59)$. Additionally, zwitterionic MPGs on other bacteria can stimulate more IL-10 and higher proportions of CD4+ FoxP3 + regulatory T cells than non-ZPS strains (10). Non-ZPSs can also promote the production of $\mathrm{T}_{\text {regs }}$ as neutrally charged cell surface $\beta$-glucan/galactan (CSGG) polysaccharides from Bifidobacterium bifidum induced $\mathrm{T}_{\text {reg }}$ cells in the intestine and suppressed inflammation in a $\mathrm{T}$ cell transfer model of colitis (27). Interestingly, MPGs on outer membrane vesicles (OMVs), which are released by many Gram-negative bacteria, can also regulate $\mathrm{T}$ cell responses similarly to MPGs on whole bacteria. B. thetaiotaomicron OMVs that singly expressed antistimulatory CPSs poorly stimulated $\mathrm{T}$ cells compared to $B$. thetaiotaomicron OMVs that singly expressed pro-stimulatory CPSs just like CPSs on whole B. thetaiotaomicron (24). B. fragilis OMVs that contained PSA induced more IL-10 production and CD4+ FoxP3 + Tregs compared to OMVs that lacked PSA, which also corresponded with the PSA effects observed on whole $B$. fragilis (60).

In addition to modulating polyclonal $\mathrm{T}$ cell responses, MPGs can regulate $\mathrm{T}$ cell responses to dominant antigens. Using a $B$. thetaiotaomicron-specific $\mathrm{CD} 4+\mathrm{T}$ cell called $\mathrm{B} \theta \mathrm{OM}, B$. thetaiotaomicron expressing anti-stimulatory CPSs was found to weakly activated $\mathrm{B} \theta \mathrm{OM} \mathrm{T}$ cells while $B$. thetaiotaomicron expressing pro-stimulatory CPSs strongly activate B $\theta \mathrm{OM} \mathrm{T}$ cells in vitro and in vivo (24). CPSs on B. thetaiotaomicron also directed the differentiation of antigen-specific T cells as $\mathrm{B} \theta \mathrm{OM}$ $\mathrm{T}$ cells in the colon differentiated into more IFN- $\gamma+$ IL-17A+ $\mathrm{T}$ cells in the presence of $B$. thetaiotaomicron containing prostimulatory CPSs than anti-stimulatory CPSs (24). These findings demonstrate that by altering MPGs, bacteria can also modulate adaptive immune responses to their dominant antigens.

\section{DISCUSSION}

MPGs play critical roles in regulating the immune responses to the microbiota in the intestine. Many MPGs enable bacteria to evade innate and adaptive immune responses by forming protecting shields around bacteria. For example, MPGs can protect bacteria from antimicrobial factors, complement deposition, and phagocytosis by innate immune cells. MPGs also promote immune tolerance by inducing the innate immune system to produce more anti-inflammatory cytokines or fewer 
pro-inflammatory cytokines as well as maturation of innate immune cells to make them better APCs for the adaptive immune system. Adaptive immune responses can also be modulated by MPGs as MPGs can block B cell and antibody responses, especially by masking surface antigens. In addition, MPGs, even on OMVs, can regulate $\mathrm{T}$ cell responses by directly serving as the $\mathrm{T}$ cell antigen or by controlling the activation and differentiation of polyclonal and antigen-specific T cells.

MPGs are critical components of the gut microbiota, and deciphering the roles of MPGs in microbiota-immune interactions in the intestine is crucial for improving human health. Despite the progress in understanding how MPGs modulate immune responses to intestinal bacteria, many immunoregulatory functions of MPGs are still poorly understood. For example, why some non-zwitterionic MPGs are anti-stimulatory whereas others are pro-stimulatory is not known. In addition, bacteriophages can regulate the immune system (61) and MPG-specific bacteriophages have been identified (62), but the interactions between MPGspecific bacteriophages, MPGs, and the immune system remain to be elucidated. Progress in this area has been hampered by the complex chemical structures of MPGs and additional analyses are required to decipher the MPG structures and the mechanisms by which they regulate

\section{REFERENCES}

1. Martens EC, Roth R, Heuser JE, Gordon JI. Coordinate regulation of glycan degradation and polysaccharide capsule biosynthesis by a prominent human gut symbiont. J Biol Chem. (2009) 284:18445-57. doi: 10.1074/jbc.M109.008094

2. Willis LM, Whitfield C. Structure, biosynthesis, and function of bacterial capsular polysaccharides synthesized by $\mathrm{ABC}$ transporter-dependent pathways. Carbohydr Res. (2013) 378:35-44. doi: 10.1016/j.carres.2013.05.007

3. Avery OT, Macleod CM, McCarty M. Studies on the chemical nature of the substance inducing transformation of pneumococcal types: induction of transformation by a desoxyribonucleic acid fraction isolated from Pneumococcus type Iii. J Exp Med. (1944) 79:137-58. doi: $10.1084 /$ jem.79.2.137

4. Mazmanian SK, Kasper DL. The love-hate relationship between bacterial polysaccharides and the host immune system. Nat Rev Immunol. (2006) 6:849-58. doi: 10.1038/nri1956

5. Porter NT, Martens EC. The critical roles of polysaccharides in gut microbial ecology and physiology. Annu Rev Microbiol. (2017) 71:349-69. doi: 10.1146/annurev-micro-102215-095316

6. Comstock LE, Kasper DL. Bacterial glycans: key mediators of diverse host immune responses. Cell. (2006) 126:847-50. doi: 10.1016/j.cell.2006.08.021

7. Krinos CM, Coyne MJ, Weinacht KG, Tzianabos AO, Kasper DL, Comstock LE. Extensive surface diversity of a commensal microorganism by multiple DNA inversions. Nature. (2001) 414:555-8. doi: 10.1038/35107092

8. Jones SE, Paynich ML, Kearns DB, Knight KL. Protection from intestinal inflammation by bacterial exopolysaccharides. J Immunol. (2014) 192:481320. doi: 10.4049/jimmunol.1303369

9. Paynich ML, Jones-Burrage SE, Knight KL. Exopolysaccharide from Bacillus subtilis induces anti-inflammatory M2 macrophages that prevent $\mathrm{T}$ cell-mediated disease. J Immunol. (2017) 198:2689-98. doi: 10.4049/jimmunol.1601641

10. Neff CP, Rhodes ME, Arnolds KL, Collins CB, Donnelly J, Nusbacher $\mathrm{N}$, et al. Diverse intestinal bacteria contain putative Zwitterionic capsular polysaccharides with anti-inflammatory properties. Cell Host Microbe. (2016) 20:535-47. doi: 10.1016/j.chom.2016.09.002 the immune system. Given the astronomical diversity of MPGs, MPGS likely have many more roles in modulating immune responses that have yet to be discovered. More studies are needed expand the known lexicon of bacterial polysaccharide-immune system interactions, and they may even lead to the discovery of new, bioactive CPS for potential use as therapeutics to improve human health. $(13,26,29,30,32,34,41,45,49,53)$.

\section{AUTHOR CONTRIBUTIONS}

SH and PA conceived the topic of this review. SH wrote the review and PA edited it.

\section{FUNDING}

These studies were funded by NIH grants R21AI142257 (to PA) and F30DK114950 (to SH).

\section{ACKNOWLEDGMENTS}

We thank the Allen lab, Eric Martens, Thad Stappenbeck and their respective labs for their contributions to this project. This article was submitted as a preprint to BioRxiv (62).
11. Avci FY, Kasper DL. How bacterial carbohydrates influence the adaptive immune system. Annu Rev Immunol. (2010) 28:107-30. doi: 10.1146/annurev-immunol-030409-101159

12. Avci FY, Li X, Tsuji M, Kasper DL. Carbohydrates and T cells: a sweet twosome. Semin Immunol. (2013) 25:146-51. doi: 10.1016/j.smim.2013.05.005

13. Baumann H, Tzianabos AO, Brisson JR, Kasper DL, Jennings HJ. Structural elucidation of two capsular polysaccharides from one strain of Bacteroides fragilis using high-resolution NMR spectroscopy. Biochemistry. (1992) 31:4081-9. doi: 10.1021/bi00131a026

14. Cobb BA, Wang Q, Tzianabos AO, Kasper DL. Polysaccharide processing and presentation by the MHCII pathway. Cell. (2004) 117:677-87. doi: 10.016/j.cell.2004.05.001

15. Dasgupta S, Erturk-Hasdemir D, Ochoa-Reparaz J, Reinecker HC, Kasper DL. Plasmacytoid dendritic cells mediate anti-inflammatory responses to a gut commensal molecule via both innate and adaptive mechanisms. Cell Host Microbe. (2014) 15:413-23. doi: 10.1016/j.chom.2014.03.006

16. Duan J, Avci FY, Kasper DL. Microbial carbohydrate depolymerization by antigen-presenting cells: deamination prior to presentation by the MHCII pathway. Proc Natl Acad Sci USA. (2008) 105:5183-8. doi: 10.1073/pnas.0800974105

17. Kalka-Moll WM, Tzianabos AO, Bryant PW, Niemeyer M, Ploegh HL, Kasper DL. Zwitterionic polysaccharides stimulate $\mathrm{T}$ cells by MHC class II-dependent interactions. J Immunol. (2002) 169:6149-53. doi: 10.4049/jimmunol.169.11.6149

18. Mazmanian SK, Liu CH, Tzianabos AO, Kasper DL. An immunomodulatory molecule of symbiotic bacteria directs maturation of the host immune system. Cell. (2005) 122:107-18. doi: 10.1016/j.cell.2005.05.007

19. Mazmanian SK, Round JL, Kasper DL. A microbial symbiosis factor prevents intestinal inflammatory disease. Nature. (2008) 453:620-5. doi: $10.1038 /$ nature 07008

20. Round JL, Mazmanian SK. Inducible Foxp3+ regulatory T-cell development by a commensal bacterium of the intestinal microbiota. Proc Natl Acad Sci USA. (2010) 107:12204-9. doi: 10.1073/pnas.0909122107

21. Round JL, Lee SM, Li J, Tran G, Jabri B, Chatila TA, et al. The Toll-like receptor 2 pathway establishes colonization by a commensal of the human microbiota. Science. (2011) 332:974-7. doi: 10.1126/science.1206095 
22. Telesford KM, Yan W, Ochoa-Reparaz J, Pant A, Kircher C, Christy MA, et al. A commensal symbiotic factor derived from Bacteroides fragilis promotes human CD39(+)Foxp3(+) T cells and Treg function. Gut Microbes. (2015) 6:234-42. doi: 10.1080/19490976.2015.1056973

23. Wang Q, McLoughlin RM, Cobb BA, Charrel-Dennis M, Zaleski KJ, Golenbock D, et al. A bacterial carbohydrate links innate and adaptive responses through Toll-like receptor 2. J Exp Med. (2006) 203:2853-63. doi: $10.1084 /$ jem. 20062008

24. Hsieh S, Porter NT, Donermeyer DL, Horvath S, Strout G, Saunders BT, et al. Polysaccharide capsules equip the human symbiont bacteroides thetaiotaomicron to modulate immune responses to a dominant antigen in the intestine. J Immunol. (2020) 204:1035-46. doi: 10.4049/jimmunol.1901206

25. Porter NT, Canales P, Peterson DA, Martens EC. A subset of polysaccharide capsules in the human symbiont bacteroides thetaiotaomicron promote increased competitive fitness in the mouse gut. Cell Host Microbe. (2017) 22:494-506 e498. doi: 10.1016/j.chom.2017.08.020

26. Speciale I, Verma R, Di Lorenzo F, Molinaro A, Im SH, De Castro C. Bifidobacterium bifidum presents on the cell surface a complex mixture of glucans and galactans with different immunological properties. Carbohydr Polym. (2019) 218:269-78. doi: 10.1016/j.carbpol.2019.05.006

27. Verma R, Lee C, Jeun EJ, Yi J, Kim KS, Ghosh A, et al. Cell surface polysaccharides of Bifidobacterium bifidum induce the generation of Foxp3(+) regulatory $\mathrm{T}$ cells. Sci Immunol. (2018) 3:aat6975. doi: 10.1126/sciimmunol.aat6975

28. Fanning S, Hall LJ, Cronin M, Zomer A, MacSharry J, Goulding D, et al. Bifidobacterial surface-exopolysaccharide facilitates commensal-host interaction through immune modulation and pathogen protection. Proc Natl Acad Sci USA. (2012) 109:2108-13. doi: 10.1073/pnas.1115621109

29. Hughes KR, Harnisch LC, Alcon-Giner C, Mitra S, Wright CJ, Ketskemety J, et al. Bifidobacterium breve reduces apoptotic epithelial cell shedding in an exopolysaccharide and MyD88-dependent manner. Open Biol. (2017) 7:160155. doi: 10.1098/rsob.160155

30. Altmann F, Kosma P, O'Callaghan A, Leahy S, Bottacini F, Molloy E, et al. Genome analysis and characterisation of the exopolysaccharide produced by Bifidobacterium longum subsp. longum 35624. PLoS ONE. (2016) 11:e0162983. doi: 10.1371/journal.pone.0162983

31. Schiavi E, Gleinser M, Molloy E, Groeger D, Frei R, Ferstl R, et al. the surface-associated exopolysaccharide of Bifidobacterium longum 35624 plays an essential role in dampening host proinflammatory responses and repressing local TH17 responses. Appl Environ Microbiol. (2016) 82:7185-96. doi: 10.1128/AEM.02238-16

32. Tahoun A, Masutani H, El-Sharkawy H, Gillespie T, Honda RP, Kuwata K, et al. Capsular polysaccharide inhibits adhesion of Bifidobacterium longum 105-A to enterocyte-like Caco-2 cells and phagocytosis by macrophages. Gut Pathog. (2017) 9:27. doi: 10.1186/s13099-017-0177-x

33. Pequegnat B, Laird RM, Ewing CP, Hill CL, Omari E, PolyF, et al. Phasevariable changes in the position of $\mathrm{O}$-methyl phosphoramidate modifications on the polysaccharide capsule of Campylobacter jejuni modulate serum resistance. J Bacteriol. (2017) 199:17. doi: 10.1128/JB.00027-17

34. Stahl M, Ries J, Vermeulen J, Yang H, Sham HP, Crowley SM, et al. A novel mouse model of Campylobacter jejuni gastroenteritis reveals key pro-inflammatory and tissue protective roles for Toll-like receptor signaling during infection. PLoS Pathog. (2014) 10:e1004264. doi: 10.1371/journal.ppat.1004264

35. Thomassin JL, Lee MJ, Brannon JR, Sheppard DC, Gruenheid S, Le Moual $\mathrm{H}$. Both group 4 capsule and lipopolysaccharide $\mathrm{O}$-antigen contribute to enteropathogenic Escherichia coli resistance to human alpha-defensin 5. PLoS ONE. (2013) 8:e82475. doi: 10.1371/journal.pone.0082475

36. Rossi O, Khan MT, Schwarzer M, Hudcovic T, Srutkova D, Duncan SH, et al. Faecalibacterium prausnitzii strain HTF-F and its extracellular polymeric matrix attenuate clinical parameters in DSS-induced colitis. PLoS ONE. (2015) 10:e0123013. doi: 10.1371/journal.pone.0123013

37. Danne C, Ryzhakov G, Martinez-Lopez M, Ilott NE, Franchini F, Cuskin F, et al. A large polysaccharide produced by Helicobacter hepaticus induces an anti-inflammatory gene signature in macrophages. Cell Host Microbe. (2017) 22:733-45 e735. doi: 10.1016/j.chom.2017.11.002

38. Ale EC, Perezlindo MJ, Burns P, Tabacman E, Reinheimer JA, Binetti AG. Exopolysaccharide from Lactobacillus fermentum Lf2 and its functional characterization as a yogurt additive. J Dairy Res. (2016) 83:487-92. doi: $10.1017 /$ S0022029916000571

39. Dertli E, Colquhoun IJ, Gunning AP, Bongaerts RJ, Le Gall G, Bonev $\mathrm{BB}$, et al. Structure and biosynthesis of two exopolysaccharides produced by Lactobacillus johnsonii FI9785. J Biol Chem. (2013) 288:31938-51. doi: 10.1074/jbc.M113.507418

40. Vinderola G, Perdigon G, Duarte J, Farnworth E, Matar C. Effects of the oral administration of the exopolysaccharide produced by Lactobacillus kefiranofaciens on the gut mucosal immunity. Cytokine. (2006) 36:254-60. doi: 10.1016/j.cyto.2007.01.003

41. Lebeer S, Verhoeven TL, Francius G, Schoofs G, Lambrichts I, Dufrene Y, et al. Identification of a gene cluster for the biosynthesis of a long, galactose-rich exopolysaccharide in Lactobacillus rhamnosus GG and functional analysis of the priming glycosyltransferase. Appl Environ Microbiol. (2009) 75:3554-63. doi: 10.1128/AEM.02919-08

42. Lebeer S, Claes IJ, Verhoeven TL, Vanderleyden J, De Keersmaecker SC. Exopolysaccharides of Lactobacillus rhamnosus GG form a protective shield against innate immune factors in the intestine. Microb Biotechnol. (2011) 4:368-74. doi: 10.1111/j.1751-7915.2010.00199.x

43. Matsuzaki C, Hayakawa A, Matsumoto K, Katoh T, Yamamoto K, Hisa K. Exopolysaccharides produced by Leuconostoc mesenteroides strain NTM048 as an immunostimulant to enhance the mucosal barrier and influence the systemic immune response. J Agric Food Chem. (2015) 63:7009-15. doi: $10.1021 /$ acs.jafc.5b01960

44. de Palencia PF, Werning ML, Sierra-Filardi E, Duenas MT, Irastorza A, Corbi AL, et al. Probiotic properties of the 2-substituted $(1,3)$-beta-D-glucanproducing bacterium Pediococcus parvulus 2.6. Appl Environ Microbiol. (2009) 75:4887-91. doi: 10.1128/AEM.00394-09

45. de Rezende CE, Anriany Y, Carr LE, Joseph SW, Weiner RM. Capsular polysaccharide surrounds smooth and rugose types of Salmonella enterica serovar Typhimurium DT104. Appl Environ Microbiol. (2005) 71:7345-51. doi: 10.1128/AEM.71.11.7345-7351.2005

46. Marshall JM, Gunn JS. The O-antigen capsule of Salmonella enterica serovar Typhimurium facilitates serum resistance and surface expression of FliC. Infect Immun. (2015) 83:3946-59. doi: 10.1128/IAI.00634-15

47. Wilson RP, Raffatellu M, Chessa D, Winter SE, Tukel C, Baumler AJ. The Vicapsule prevents Toll-like receptor 4 recognition of Salmonella. Cell Microbiol. (2008) 10:876-90. doi: 10.1111/j.1462-5822.2007.01090.x

48. Santhanam SK, Dutta D, Parween F, Qadri A. The virulence polysaccharide Vi released by Salmonella Typhi targets membrane prohibitin to inhibit T-cell activation. J Infect Dis. (2014) 210:79-88. doi: 10.1093/infdis/j iu064

49. Wilson RP, Winter SE, Spees AM, Winter MG, Nishimori JH, Sanchez JF, et al. The Vi capsular polysaccharide prevents complement receptor 3-mediated clearance of Salmonella enterica serotype Typhi. Infect Immun. (2011) 79:8307. doi: 10.1128/IAI.00961-10

50. Caboni M, Pedron T, Rossi O, Goulding D, Pickard D, Citiulo F, et al. An $\mathrm{O}$ antigen capsule modulates bacterial pathogenesis in Shigella sonnei. PLoS Pathog. (2015) 11:e1004749. doi: 10.1371/journal.ppat.1004749

51. Chen Y, Zhang M, Ren F. A role of exopolysaccharide produced by Streptococcus thermophilus in the intestinal inflammation and mucosal barrier in Caco-2 monolayer and dextran sulphate sodium-induced experimental murine colitis. Molecules. (2019) 24:513. doi: 10.3390/molecules240 30513

52. Attridge SR, Fazeli A, Manning PA, Stroeher UH. Isolation and characterization of bacteriophage-resistant mutants of Vibrio cholerae O139. Microbial Pathogenesis. (2001) 30:237-45. doi: 10.1006/mpat.1006. 2000.0426

53. Attridge SR, Holmgren J. Vibrio cholerae O139 capsular polysaccharide confers complement resistance in the absence or presence of antibody yet presents a productive target for cell lysis: implications for detection of bactericidal antibodies. Microb Pathog. (2009) 47:314-20. doi: 10.1016/j.micpath.2009.09.013

54. Qadri F, Svennerholm AM, Shamsuzzaman S, Bhuiyan TR, Harris JB, Ghosh AN, et al. Reduction in capsular content and enhanced bacterial susceptibility to serum killing of Vibrio cholerae O139 associated with the 2002 cholera epidemic in Bangladesh. Infect Immun. (2005) 73:6577-83. doi: 10.1128/IAI.73.10.6577-6583.2005 
55. Paik W, Alonzo F III, Knight KL. Probiotic exopolysaccharide protects against systemic Staphylococcus aureus infection, Inducing dual-functioning macrophages that restrict bacterial growth and limit inflammation. Infect Immun. (2019) 87:18. doi: 10.1128/IAI.00791-18

56. Cress BF, Englaender JA, He W, Kasper D, Linhardt RJ, Koffas MA. Masquerading microbial pathogens: capsular polysaccharides mimic host-tissue molecules. FEMS Microbiol Rev. (2014) 38:660-97. doi: 10.1111/1574-6976.12056

57. Bloem K, Garcia-Vallejo JJ, Vuist IM, Cobb BA, van Vliet SJ, van Kooyk Y. Interaction of the capsular polysaccharide a from Bacteroides fragilis with DCSIGN on human dendritic cells is necessary for its processing and presentation to T cells. Front Immunol. (2013) 4:103. doi: 10.3389/fimmu.2013.00103

58. Hashimoto M, Waki J, Nakayama-Imaohji H, Ozono M, Hashiguchi S, Kuwahara T. TLR2-stimulating contaminants in glycoconjugate fractions prepared from Bacteroides fragilis. Innate Immun. (2017) 23:449-58. doi: 10.1177/1753425917714313

59. Kreisman LS, Cobb BA. Glycoantigens induce human peripheral $\operatorname{Tr} 1$ cell differentiation with gut-homing specialization. J Biol Chem. (2011) 286:8810-8. doi: 10.1074/jbc.M110.206011

60. Shen Y, Giardino Torchia ML, Lawson GW, Karp CL, Ashwell JD, Mazmanian SK. Outer membrane vesicles of a human commensal mediate immune regulation and disease protection. Cell Host Microbe. (2012) 12:509-20. doi: 10.1016/j.chom.2012.08.004

61. Gogokhia L, Buhrke K, Bell R, Hoffman B, Brown DG, Hanke-Gogokhia $\mathrm{C}$, et al. Expansion of bacteriophages is linked to aggravated intestinal inflammation and colitis. Cell Host Microbe. (2019) 25:285-99 e288. doi: 10.1016/j.chom.2019.01.008

62. Porter NT, Hryckowian AJ, Merrill BD, Gardner JO, Singh S, Sonnenburg JL, et al. Multiple phase-variable mechanisms, including capsular polysaccharides, modify bacteriophage susceptibility in Bacteroides thetaiotaomicron. (2019). bioRxiv 521070. doi: 10.1101/521070

Conflict of Interest: The authors declare that the research was conducted in the absence of any commercial or financial relationships that could be construed as a potential conflict of interest.

Copyright (c) 2020 Hsieh and Allen. This is an open-access article distributed under the terms of the Creative Commons Attribution License (CC BY). The use, distribution or reproduction in other forums is permitted, provided the original author(s) and the copyright owner(s) are credited and that the original publication in this journal is cited, in accordance with accepted academic practice. No use, distribution or reproduction is permitted which does not comply with these terms. 